element contents of different species at different stages of growth and on the possible dangers of lead toxicity. The interactions between major and trace elements on ion transport and exchange in plant tissues continue to receive attention and a start has been made on the role of vacuolar osmotic potential in nutrient uptake. Selected soil groups are being used for evaluating the properties that govern soil productivity, and investigations of responses to fertilizers have included methods and times of application.

\section{The Furniture Industry Research Association}

THE third annual report of the Furniture Industry Research Association shows that, during 1963, a significant increase in memborship occurred, and that total membership now amounts to 712 (Pp. 16. Stevenage: The Furniture Industry Research Association, 1964). This includes 538 firms registored with the Furniture Development Council, which cover about 80 per cent by value of the turnover of the industry. Considerable progress is reported on all present research projects covering such topics as the determination of the loads in chair frames, causes of show-through in veneered chip-board, the checking of veneers, and the investigation of the properties of floxible polyother foams. Work has been completed on polyvinyl acetate adhesives and on the development of a glossing-up test for matt lacquers. The optimum conditions for spray-gun operation have been determined by relating the quality of the finish to the waste of lacquer through fog and bounce. About 20 per cent of tho rosearch staff investigators have beon concernod with the investigation of ad hoc enquiries, such as the performanco testing of prototype furniture, causes of warping of panols, comparative testing of various finishes, the critical examination of chairs from the point of view of eomfort, the suitability of different timbers, the noisiness of table tops and various fault investigations. Tho Technical Information Service has beon called on to meet an incroasing demand. A total of 2,200 enquiries submitted by 542 organizations has been dealt with. A now publication series, known as FIRA Notes, has boen introduced with the view of giving in easily digestiblo form concise and up-to-date information drawn from the Association's own sources and elsewhere.

\section{Rugby School Natural History Society}

THE ninety-seventh issue of the report of the Rugby School Natural History Society contains details of the archæological excavations carried out at Caves Inn, near Shawell, in 1963 by the Rugby Archrological Society and members of Rugby School (Pp. $22+2$ plates. Rugby: Rugby School Natural History Society, 1964). The hill by Caves Inn Farm is referred to as 'Tripontium and is mentioned in the sixth itinerary of Antonius. Historians, through the ages, have used this itinerary in conjunction with the name of the hill to try to locate it. While there is no firm evidence of its identification, its situation in Roman miles fits the information in the itinerary. The evidence found so far suggests that the site consisted of a 'Mansio', surroundod by a settlement. Another article in the report includes some observations of solar activity made at the Temple Observatory during the summer term, 1963, as well as an account of the work of the Conservation Corps at Scolt Hoad by I. R. Whitehead.

\section{The Cole Library: University of Reading}

THE books on zoology and early modicino, colloctod by the late Prof. F. J. Cole, have now been moved from his home at Kingwood, Oxfordshire, to the new Library Building of the Univorsity of Reading at Whiteknights Park, where they occupy an air-conditioned room in the special collections soction on the fifth floor (soe also Nature, 188, 1148; 1960). The Colo Library comprises eight thousand volumes dating from 1472 to the present day, and it contains many rare itoms. Author, titlo and subject catalogues were prepared by Prof. Colo, and are a valuable aid to tho reader. A chronological catalogue down to the end of the eightoenth contury is now being made by Dr. N. B. Eales, and this will include biographies and translations.

\section{Scottish Journal of Geology}

THE first part of a new geological journal, the Scottish Journal of Geology, is due to appear in the autumn of this year. The new journal is the result of an amalgamation of the Transactions of the Geological Society of Edinburgh and the Transactions of the Geological Society of Glasgow. The Councils of both Societies consider that the now journal will provide a better forum for the presentation of the scientific work of the two Societies and of other work on Scottish geology. They also intend to continue their policy of oncouraging the publication of geological papers of general or specialist interest. The journal will be published throo times a yoar. Subscription rates will be $£ 4$ per annum for institutional subscribors and 30s. per annum for Fellows of either Society. Enquiries about subscriptions or editorial matters should be addressed to the Editors, Scottish Journal of Geology, Twooddale Court, 14 High Stroct, Edinburgh.

\section{The Longest Road}

THe Trans-Canada Highway, the longest pavod road in the world, which stretches for 5,000 miles (with two short ferry-breaks) from St. John's, Newfoundland, to Victoria, Vancouver Island, was originally opened in 1962, and has already transformed the conception of east-west direct communication by road in the Dominion. It is now practicable for Canadians to motor across this vast territory without leaving thoir own country. The first car-ferry is across the Gulf of St. Lawrence to Cape Breton Island. This is now artificially joined to Nova Scotia by a causoway constructed by literally filling in the ono mile wide and $200-\mathrm{ft}$. deep Canso Strait between Capo Breton Island and the mainland with some 5 million cubic yards of rock, an engineering feat of no mean order, considering that bridging this gap, often subjoct to fierce spring tides and ice jams, was abandoned as being an impracticable task. From Nova Scotia the highway passes through New Brunswick to Quebec, thence via Montreal, across Ontario by Ottawa north of the Great Lakes by Sault Sainte Mario and Wawa to Fort William. In this stretch another great engineering triumph is recorded. Between Sault Sainte Marie and Fort William, a distance of some 400 miles there occurs a wilderness area called by the Canadians 'The Gap'. Before the advent of this great highway, this feature had constituted a barrier which had virtually split the Dominion in two; its avoidance was only possible by following northerly loop-roads adding hundreds of miles to the distance to be traversed. In a vividly written and illustrated article in The Lamp (quarterly magazine of the Standard Oil Company of Now Jersey, 46, No. 1; 1964), the hazards of this wilderness aro well summed up: "The Gap itself was just 164 miles across, but it was split up by moro than a hundred rivers, thousands of lakes, deop ravines, granito lodges-and muskeg. Muskeg is a Canadian highway ongineor's peculiar nightmare. It is seemingly bottomless mud and silt, sometimes a mile deep, which freezes solid in winter but in summer becomos quicksand. Muskog can swallow mon and machinery-even roads. One section of the Trans-Canada, ropresenting an entire day's work, disappeared without a trace before the next sun came up." From Fort William, the highway traversos Manitoba by Winnipeg, Saskatchewan via Regina, thence to Calgary, Alberta, into British Columbia, here through tho most difficult section, Rogers Pass, 4,335 ft. O D. with Rocky Mountain peaks rising $10,000 \mathrm{ft}$. on either side. A.t Vancouver a short sea ferry complotes the journey along this amazing road to Victoria, Vancouver Island. 